\title{
Cariology in India: A Chance or a Challenge?
}

\author{
Neetha Shenoy \\ Journal of Operative Dentistry and Endodontics (2020): 10.5005/jp-journals-10047-0102
}

"Every Challenge is a Chance to Succeed"

Dental caries are one of the most prevalent oral diseases and are one of the leading causes of tooth loss in all age-groups. It is the main burden that affects the quality of life as well as the nation. ' Untreated dental caries can lead to sequelae like severe pain, abscess, swelling, trismus, space infection, and finally tooth loss. It also has a crippling effect on the dentition and leads to malnutrition due to difficulty in chewing any coarse food. ${ }^{2}$ The rationale of this essay is to highlight the major challenges in cariology in India and the chances to tackle them more practically.

\section{Cariology in India: Challenges and CHANCES}

\section{Challenge 1: Multifactorial Etiology of Dental Caries}

Dental caries arise due to the interplay between various factors such as microbial factors, host-related factors such as poor oral hygiene, frequent intake of refined carbohydrates and sugars, wrong feeding habits among infants, systemic conditions such as diabetes, low salivary flow rate, stress, altered immune response, and genetic polymorphism. Thus, a generalized treatment approach that fits one and all is not possible. ${ }^{3}$

Chance: A customized treatment plan based on an individual's caries risk assessment is the need of the hour. The recent studies highlight that the traditional factors have been re-delegated as "ecological pressures," and dental caries arise due to the "dysbiosis." ${ }^{4}$

\section{Challenge 2: Lack of Data Related to the Status of Dental Caries in India}

"Unity in diversity" is the beauty of our motherland. Our country is marked by unique cultural and socioeconomic variations and diverse food habits. Being one of the most populous country, more than $72 \%$ of the people in India reside in villages and are inaccessible to oral health-care facilities. ${ }^{5}$ There are several challenges in delivering dental health-care facilities to the rural population due to the lack of manpower, low socioeconomic status, illiteracy, and lack of awareness.

Chance: It is necessary to assess oral health status and treatment needs in urban as well as rural population. There is an urgent need for comprehensive oral health educational programs. The government support would be required in providing accessible and affordable oral health services to the rural communities. Training the school teachers, social workers, and Anganwadi workers in collection of basic interstate data on the prevalence of dental and also highlighting the importance of oral health care and preventive measures among the public is the need of the hour. The use of
Department of Conservative Dentistry and Endodontics, Manipal College of Dental Sciences, Manipal Academy of Higher Education, Manipal, Karnataka, India

Corresponding Author: Neetha Shenoy, Department of Conservative Dentistry and Endodontics, Manipal College of Dental Sciences, Manipal Academy of Higher Education, Manipal, Karnataka, India, Email: neetha.gshenoy@manipal.edu

How to cite this article: Shenoy N. Cariology in India: A Chance or a Challenge? J Oper Dent Endod 2020;5(2):109-110.

Source of support: Nil

Conflict of interest: None

technology, such as various apps, helps to provide awareness and promote oral health care in remote areas. $^{6}$

\section{Challenge 3: Lack of Oral Health Awareness}

Perception of the general public that oral diseases as "nonlife threatening" has made dental caries as a "silent epidemic." By the time the patient presents in the dental clinic, a major amount of loss of the tooth structure has already taken place. This can lead to a "vicious restorative cycle" that eventually results in tooth loss. Sucrose in the diet is the major cause of dental caries due to which it is regarded as an arch criminal. It promotes colonization of Streptococcus mutans. Frequent snacking and faulty toothbrushing technique can lead to increased risk of dental caries (Fig. 1). ${ }^{7}$

Chance: The dental practitioner can bring about behavioral changes and motivation in patients. Oral hygiene instructions that involve the demonstration of correct brushing technique, use of dental floss and other interdental aids, use of fluoride mouth rinses, and dietary modifications can instill some form of motivation in patients and positively influence dental health. A good dentist should also be a good communicator!

\section{Challenge 4: Targeting Bacteria of Dental Caries is Unfruitful!}

Latest RNA and DNA studies have established a diverse bacterial ecosystem, such as Fusobacterium, Scardovia wiggsiae especially in early childhood caries, Veillonella, Lactobacillus, and apart from the "keystone" bacteria S. mutans. Dental caries are now regarded as a polymicrobial disease..$^{8,9}$

\section{Challenge 5: Oral Systemic Link}

Untreated dental caries act as a focus of infection and are linked to systemic diseases, such as rheumatic endocarditis, diabetes, cancer, and chronic obstructive pulmonary diseases.

(0) The Author(s). 2020 Open Access This article is distributed under the terms of the Creative Commons Attribution 4.0 International License (https:// creativecommons.org/licenses/by-nc/4.0/), which permits unrestricted use, distribution, and non-commercial reproduction in any medium, provided you give appropriate credit to the original author(s) and the source, provide a link to the Creative Commons license, and indicate if changes were made. The Creative Commons Public Domain Dedication waiver (http://creativecommons.org/publicdomain/zero/1.0/) applies to the data made available in this article, unless otherwise stated. 


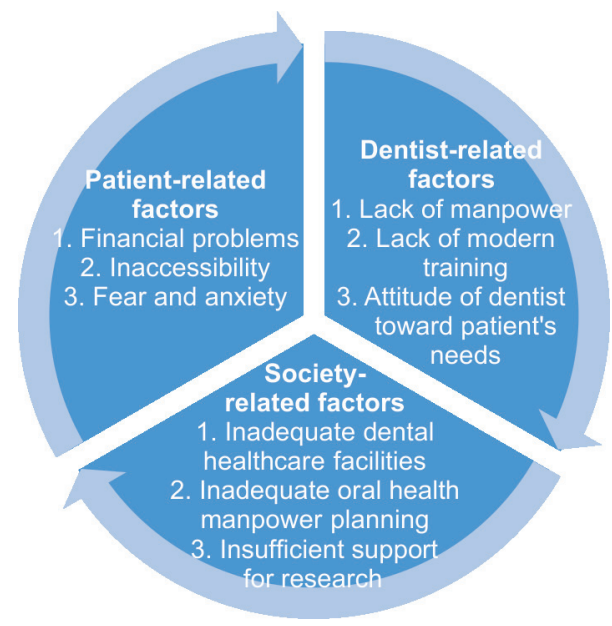

Fig. 1: Barriers to the oral health care ${ }^{5}$

Chance: Oral hygiene maintenance should never be neglected. A good oral health results in good systemic health. ${ }^{10}$

\section{Future Directions ${ }^{11,12}$}

- Detection of early incipient and cavitated lesions.

- Research in remineralization.

- Well-designed surveys to assess the dental caries status in India.

- Educating the general public.

- Collaborative multidisciplinary research work in cariology.

- New fluoride-releasing materials or probiotic materials.

\section{ConcLusion}

Dental caries are globally present, and cariology in India is not always free from challenges. Nevertheless, the fact that the dental caries are diagnosed and even can be reversed if detected early is the chance and a ray of hope. Prompt diagnosis, early identification of high-risk population, and patient education are the need of the hour.

\section{References}

1. Miglani S. Burden of dental caries in India: current scenario and future strategies. Int J Clin Pediatr Dent 2020;13(2):155. DOI: 10.5005/ jp-journals-10005-1733.

2. Fejerskov $\mathrm{O}$. Changing paradigms in concepts on dental caries: consequences for oral health care. Caries Res 2004;38(3):182-191. DOI: 10.1159/000077753.

3. Philip N, Suneja B, Walsh LJ. Ecological approaches to dental caries prevention: paradigm shift or shibboleth? Caries Res 2018;52(12):153-165. DOI: 10.1159/000484985.

4. Balaji SM. Dental caries: research perspective. Indian J Dent Res 2018;29(1):3. DOI: 10.4103/ijdr.IJDR_61_18.

5. Salunke S, Shah V, Ostbye T, et al. Prevalence of dental caries, oral health awareness and treatment-seeking behavior of elderly population in rural Maharashtra. Indian J Dent Res 2019;30(3):332. DOI: 10.4103/ijdr.IJDR_356_17.

6. Chakraborty M, Saha JB, Bhattacharya RN, et al. Epidemiological correlates of dental caries in an urban slum of West Bengal. Indian journal of public health. 1997;41(2):56.

7. Maru AM, Narendran S. Epidemiology of dental caries among adults in a rural area in India. J Contemp Dent Pract 2012;13(3):382-388. DOI: 10.5005/jp-journals-10024-1155.

8. Simón-Soro A, Mira A. Solving the etiology of dental caries. Trends Microbial 2015;23(2):76-82. DOI: 10.1016/j.tim.2014.10.010.

9. Banas JA, Drake DR. Are the mutans streptococci still considered relevant to understanding the microbial etiology of dental caries? BMC Oral Health 2018;18(1):129. DOI: 10.1186/s12903-018-0595-2.

10. Casamassimo PS. Relationships between oral and systemic health. Pediatr Clin North Am 2000;47(5):1149-1157. DOI: 10.1016/s00313955(05)70261-3.

11. Petersen PE, Ogawa H. Prevention of dental caries through the use of fluoride-the WHO approach. Commun Dent Health 2016;33(2):66-68. DOI: 10.1922/CDH_Petersen03.

12. Prabakar J, Arumugham IM, Sakthi DS, et al. Prevalence and comparison of dental caries experience among 5 to 12 year old school children of Chandigarh using dft/DMFT and SiC index: a crosssectional study. J Family Med Prim Care 2020;9(2):819. DOI: 10.4103/ jfmpc.jfmpc_781_19. 